\title{
Nové možnosti modelu BILAN
}

\section{ADAM VIZINA, STANISLAV HORÁČEK, MARTIN HANEL}

Klíčová slova: hydrologická bilance - model BILAN - grafické uživatelské rozhraní - R - Shiny - webová aplikace

\section{SOUHRN}

Model BILAN je používán k simulacím hydrologické bilance na českých i evropských povodích v řadě projektů aplikovaného výzkumu i hydrologických studií. Příspěvek představuje vývoj tohoto modelu během několika posledních let. Popisuje jednak některé změny $v$ modelu samotném (začlenění užívání vod, možnost kalibrace soustavy povodí, ukládání stavových veličin), jednak se zabývá přepracovaným uživatelským rozhraním, doplněným o grafické výstupy a dalši prvky pro interaktivní práci s modelem. Zmíněno je také rozhraní pro prostředí $R$ a jeho webová verze. Závěrem jsou uvedeny príklady použití modelu ve studiích vyžadujicích simulaci chování povodí, at' už pro současný stav, nebo pro podmínky klimatické změny.

\section{ÚVOD}

Konceptuální model BILAN, simulující hydrologickou bilanci v denním či měsíčním časovém kroku (popis modelu uvádí např́klad Tallaksen a van Lanen, 2004), je ve Výzkumném ústavu vodohospodářském T. G. Masaryka vyvíjen a používán od 90. let 20. století. $V$ roce 2011 byla původní softwarová implementace modelu BILAN, napsaná v jazyce Object Pascal, kompletně přepsána do jazyka C++, čímž se výrazně zjednodušil další vývoj modelu. Zároveň byla vytvořena dvě rozhraní k modelu (popsaná Beranem aj., 2011): grafické uživatelské rozhraní (GUI) založené na multiplatformní knihovně Qt a balík pro statistické a programovací prostředí R (R Core Team, 2015). Obě rozhraní se vzájemně doplňují GUI zpř́istupňuje model širokému spektru uživatelů a díky vizualizacím představuje efektivní nástroj pro kalibraci povodí, balík pro R umožňuje pokročilým uživatelům využít výhod hromadného zpracování a skriptování modelu v kombinaci s rozsáhlými možnostmi poskytovanými vlastním prostředím $\mathrm{R}$.

Model i obě rozhraní jsou nadále udržovány a rozvíjeny podle potřeb výzkumných úkolů a požadavků uživatelů. Samostatně byl popsán nově implementovaný optimalizační algoritmus využívající evoluční metody (Máca aj., 2013), tento prríspěvek poskytuje přehled dalších nových vlastností a možností modelu. Základy propojeného modelu BILAN jsou uvedeny v článku (Vizina a Hanel, 2011). Porovnání výpočetního algoritmu pro denní a měsiční verzi je uveden v př́spěvku (Horáček aj., 2009).

\section{ZMĚNY V MODELU A JEHO SOFTWAROVÉ IMPLEMENTACI}

\section{Výpočetní jádro}

Do bilančních rovnic modelu byly zahrnuty veličiny užívání vod, což rozšířilo oblast použití modelu na řešení vodohospodářské bilance. $V$ případě zvoleného užívání do modelu vstupují neovlivněné řady pozorovaných odtoků spolu s veličinami užívání vod, jimiž jsou odběry z povrchových vod, odběry z podzemních vod a vypouštění do povrchových vod. Experimentálně je doplňuji neevidované odběry z povrchových vod, které mají být iterativně odhadovány podle vodohospodářské bilance.

Nově je možné ukládat aktuální hodnoty stavových veličin modelu (zásoby v nádržích) a následně uložený stav využít při výpočtu začínajícím ve zvoleném časovém kroku. Toho se využívá například při simulaci nově doplněné části časové raady, jež navazuje na stávající řadu, pro niž jsou známé parametry modelu.

$\checkmark$ nastavení optimalizace je novinkou možnost stanovit řadu vah, které budou použity při výpočtu optimalizačního kritéria. Lze tak zvýšit vliv významných úseků řady, nebo naopak eliminovat období nespolehlivých dat. Optimalizační kritérium se volitelně počítá také z řad základního odtoku (modelovaného a určitou metodou odvozeného z pozorování).

Model BILANje koncipován jako celistvý, s parametry reprezentujícími celé povodí a kalibrovanými pro toto povodí nezávisle na okolních. Při tomto prístupu se tudiž $\checkmark$ hodnotách parametrů nemusí odrazit podobnost sousedních povodí a v určitých prípadech může model simulovat odtoky z mezipovodí jako záporné. Tento nedostatek vedl k tomu, že byla pripravena optimalizace, která zohledňuje vztah mezi odtokem z výše položeného a níže položeného povodí, jehož je menší povodí součástí. Libovolný počet povodí je tak možno uspořádat do soustavy, v níz je stejně jako doposud hydrologická bilance počitána pro každé povodí zvlášte. Přii optimalizaci parametrů těchto povodí se využívají stejné algoritmy jako v prípadě samostatných povodí, liší se však v optimalizačním kritériu, které pro soustavu přidává penalizaci pro záporný odtok z mezipovodí mezi níže a výše položeným povodím.

Kromě těchto hlavních rozšíření byly doplněny funkce týkající se kopírování modelu, načitání a ukládání vstupních a výstupních souborů, transformace veličin, zacházení s chybějícími hodnotami apod.

\section{Grafické uživatelské rozhraní}

Jelikož byla předchozí verze grafického uživatelského rozhraní určena pro vyhodnocování jediného povodí, bylo rozhraní zásadně upraveno, aby bylo možno pracovat s více povodími v soustavě. V současnosti se skládá ze tří hlavních oddílů: seznamu načtených povodí či variant výpočtu téhož povodí, nastavení výpočtu a optimalizačního algoritmu (včetně metody výpočtu potenciální evapotranspirace, stanovení mezí parametrů, prípadně uspořádání povodí v soustavě apod.) a prehledu výsledných hodnot s jejich vizualizací. Grafické prostředí modelu je zobrazeno na obr. 1.

U seznamu povodí byly doplněny nástroje pro manipulaci se vstupními daty. Je možné vytvářet duplikáty vstupních souborů (klonování), popř. vstupní data transformovat (a to i po jednotlivých měsících). Tyto možnosti přispívají k efektivnímu srovnávání variant výpočtu a prípravě scénářových dat, at už pro meteorologické veličiny, nebo užívání vod. 


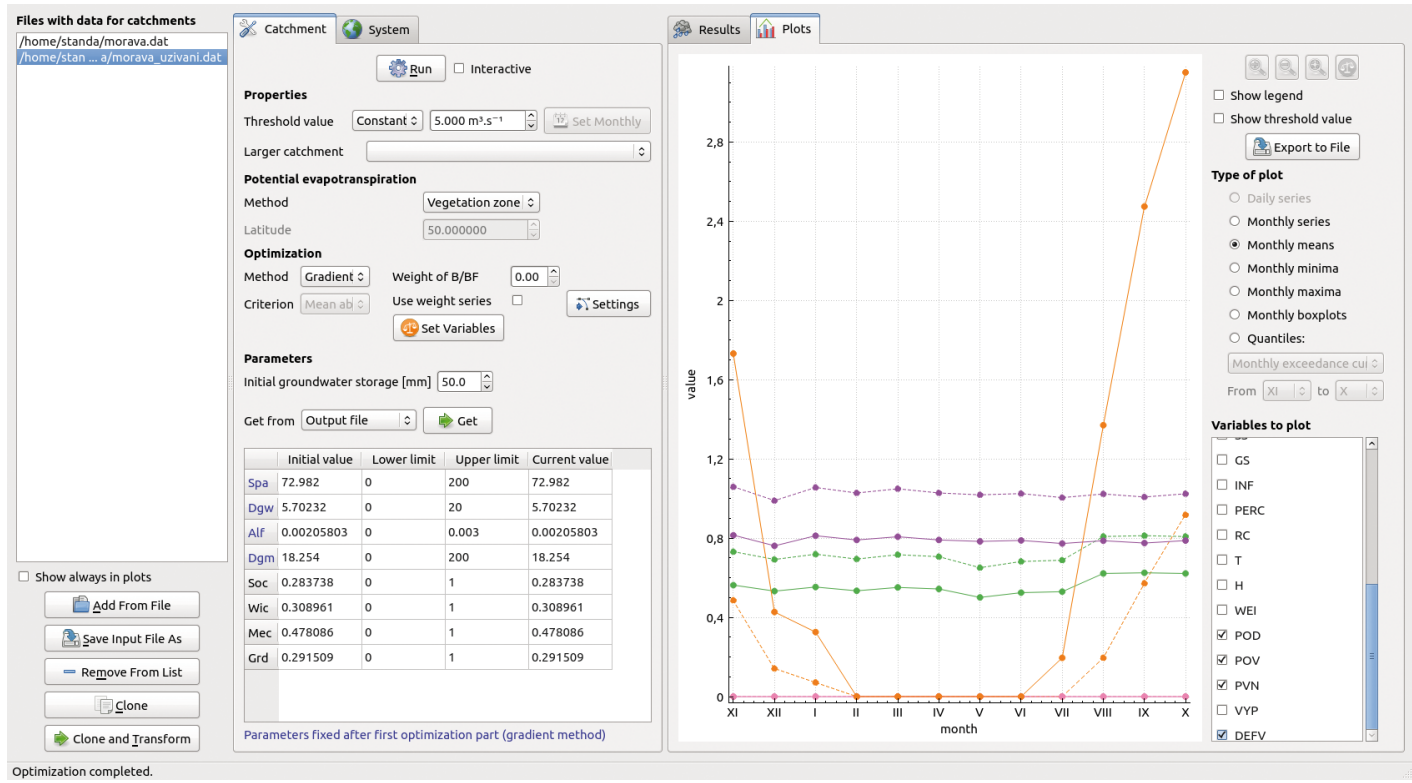

Obr. 1. Uživatelské prostředí modelu BILAN Fig. 1. User interface of the BILAN model
Novou volbou v nastavení optimalizace je použití řady vah, které Ize automaticky nastavit jako nulové pro chybějící či záporné hodnoty pozorovaného odtoku, prípadně pro uživatelem zadané období. U modelu s denním časovým krokem Ize nově vypočítat řadu základního odtoku metodou klouzavých minim z 30denního časového intervalu, která může být využita při takové kalibraci, jež základnímu odtoku přiřazuje určitou váhu.

Protože optimalizace soustavy využívá stejné algoritmy jako optimalizace samostatného povodí, neliší se ani její nastavení. Je však samozřejmě nutné zadat strukturu soustavy, která se schematicky zobrazí jako stromový seznam. Nastavení optimalizace je možné uložit do prostého textového souboru pro opětovné použití.

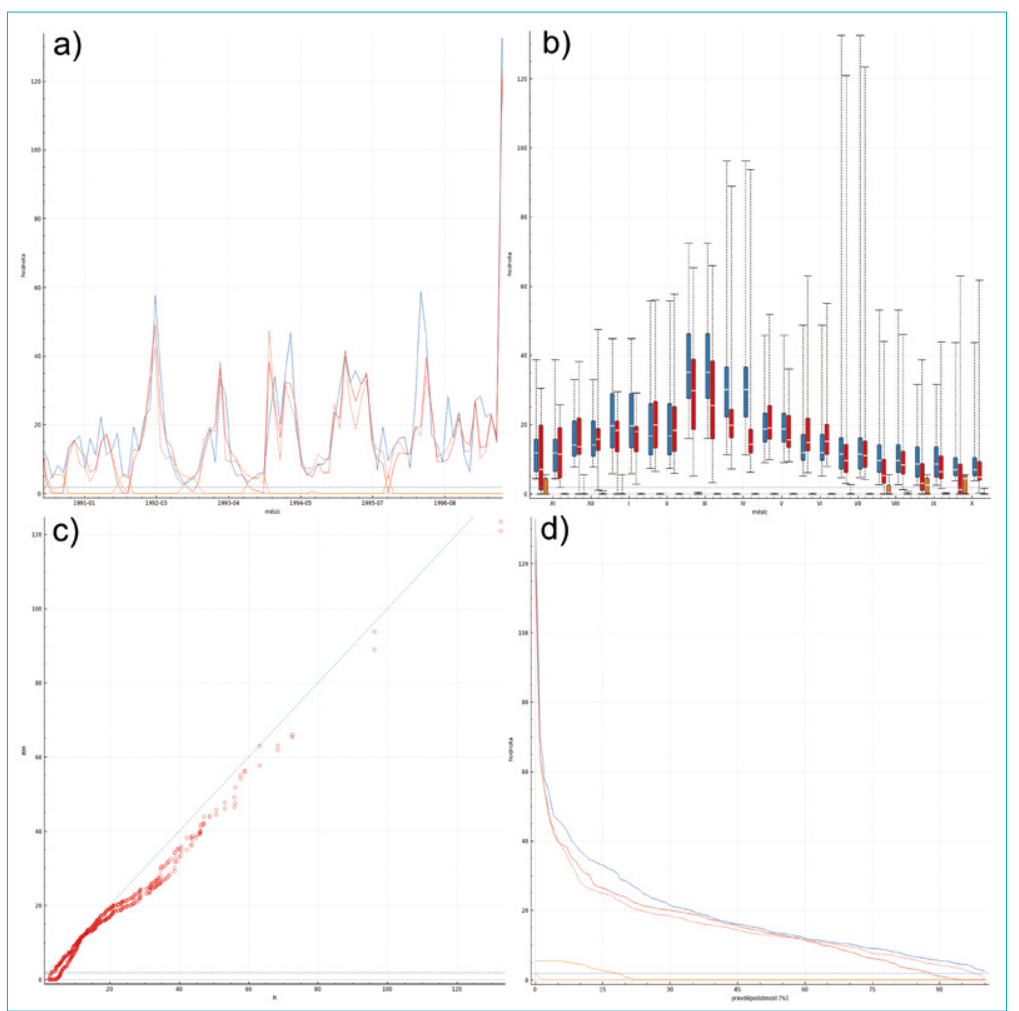

Výsledky modelování, ukládané do výstupních souborů, zahrnují hodnoty kalibrovaných parametrů, denní či měsíční časové řady veličin a jejich měsíční charakteristiky. Přidáno bylo grafické znázornění uživatelem zvolených veličin. K dispozici jsou různé druhy grafư: denní či měsiční řady, měsiční charakteristiky (průměry, minima, maxima, krabicové grafy) a kvantilové grafy, jež zahrnují čáry překročení, Gumbelovy extremální grafy (grafy počátečních a koncových úseků čar překročení) a Q-Q graf pozorovaného a modelovaného celkového odtoku; tyto grafy lze vyhodnocovat také pro zadanou sezonu. Všechny grafy je možno exportovat, u grafů řad Ize interaktivně měnit měřítko a nastavovat období pro kalibraci. Grafy umožňují zobrazit více povodí či variant výpočtů najednou, což opět usnadňuje expertní kalibraci. Možnosti (př́klady) grafických výstupů jsou uvedeny na obr. 2.

Veškeré výstupy mohou být kromě jednotek odtokové výšky uváděny také v jednotkách objemu. Z funkcí jádra byly doplněny také veličiny užívání vod, k nim jsou navíc dopočítávány nedostatkové objemy (Bonacci, 1993) za předpokladu, že uživatel určí prahovou hodnotu (například minimální zůstatkový průtok), která může být specifická pro každý měsíc.

Vliv nastavení výpočtu na výsledky Ize názorně posuzovat v režimu interaktivního spouštění modelu. $V$ něm dochází $k$ automatickému přepočítání modelu a k aktualizaci výsledků včetně grafů při jakékoliv změně vstupů (mezi něž spadají volby jako nastavení optimalizace, vstupních parametrů, transformace vstupních veličin nebo velikost prahové hodnoty).

Grafické uživatelské prostředí modelu BILAN je dostupné po domluvě s autory článku. K dispozici je i uživatelská příručka dostupná na webových stránkách bilan.vuv.cz (v českém a anglickém jazyce), jež pokrývá všechny vlastnosti programu a jejiž součástí je také popis matematického konceptu modelu.

Obr. 2. Př́klady grafických výstupů modelu BILAN: a) časové řady (modře - pozorovaný odtok, červeně - modelovaný odtok, hnědě - nedostatkové objemy), b) krabicový graf, c) Q-Q graf mezi modelovaným a pozorovaným odtokem, d) čáry překročení pro odtoky a nedostatkový objem

Fig. 2. Examples of graphical outputs from the BILAN model: a) time series (blue observed runoff, red - modelled runoff, brown - deficit volumes), b) boxplot chart type, c) qq plot between modelled and observed runoff, d) flow duration curve for runoffs and deficit volumes 


\section{Balík pro prostředí $\mathrm{R}$}

Do balíku pro prostředí R nazvaného „bilan“ (Kašpárek aj., 2014) byla převzata podpora pro nové vlastnosti jádra (uživání vod, aktuální stav, soustava povodi atd.), balík na rozdíl od GUI obsahuje veškerou novou funkcionalitu. Balík zároveň slouží pro experimentování s nově připravovanými funkcemi, v současnosti je v něm tak možné používat libovolný časový krok (v praxi napríklad týdenní), testovat pozměněnou strukturu modelu či využít při kalibraci jiné veličiny než celkový a základní odtok.

Balík obsahuje kompletní dokumentaci všech funkcí a Ize jej kompilovat na více platformách. $V$ závěru roku 2013 byl zveřejněn na oficiálním úložišti balíků pro R zvaném CRAN (Comprehensive R Archive Network), kde zůstává $v$ současnosti archivován, kvůli problémům nalezeným dynamickou analýzou kódu již však tato verze není prímo príistupná.

\section{Webová aplikace}

Pro prostředí R vzniklo několik nástrojů určených pro tvorbu webových aplikací, z nichž se nejvýznamnějším stal balík Shiny (Chang aj., 2015). Tento balík umožňuje snadno připravit webovou aplikaci sestávající z uživatelského rozhraní a serverové části, a to pouze prostrednictvím jazyka R, bez znalosti webových technologií. Takovou aplikaci lze provozovat jak lokálně, tak pomocí serverového programu Shiny Server.

Pro model BILAN je webová aplikace využívající Shiny dostupná na adrese bilan.vuv.cz/shiny/bilan. Aplikace obsahuje vzorová data pro povodí, Ize však načíst i data vlastní. Nastavení kalibrace odpovídá možnostem balíku, k dispozici je rovněž vytváření více modelů a jejich vzájemné srovnávání. To ve spojení s nástroji na diagnostiku úspěšnosti modelu (včetně různých typů grafů) nabízi podobně efektivní způsob kalibrace povodí jako desktopová aplikace, nevýhodou však je pomalejší odezva a absence interaktivního režimu. Př́klad výstupu webové aplikace je uveden na obr.3.

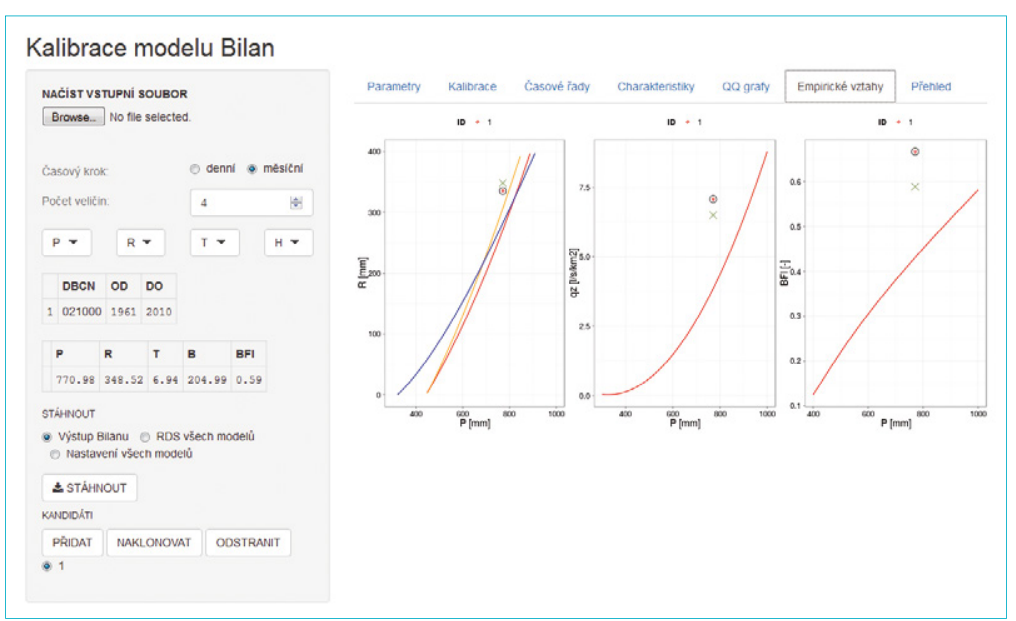

Obr. 3. Webová aplikace - zobrazení empirických vztahů mezi srážkou a odtokem, specifickým odtokem a indexem základního odtoku

Fig. 3. Web application - showing the empirical relationships between precipitation and runoff, specific runoff and baseflow index

\section{MOŽNOSTI POUŽITÍ MODELU BILAN}

Využití modelu BILAN je možné rozdělit do několika úrovní. Mezi primární patří modelování hydrologické bilance na povodí, které je hydrologicky

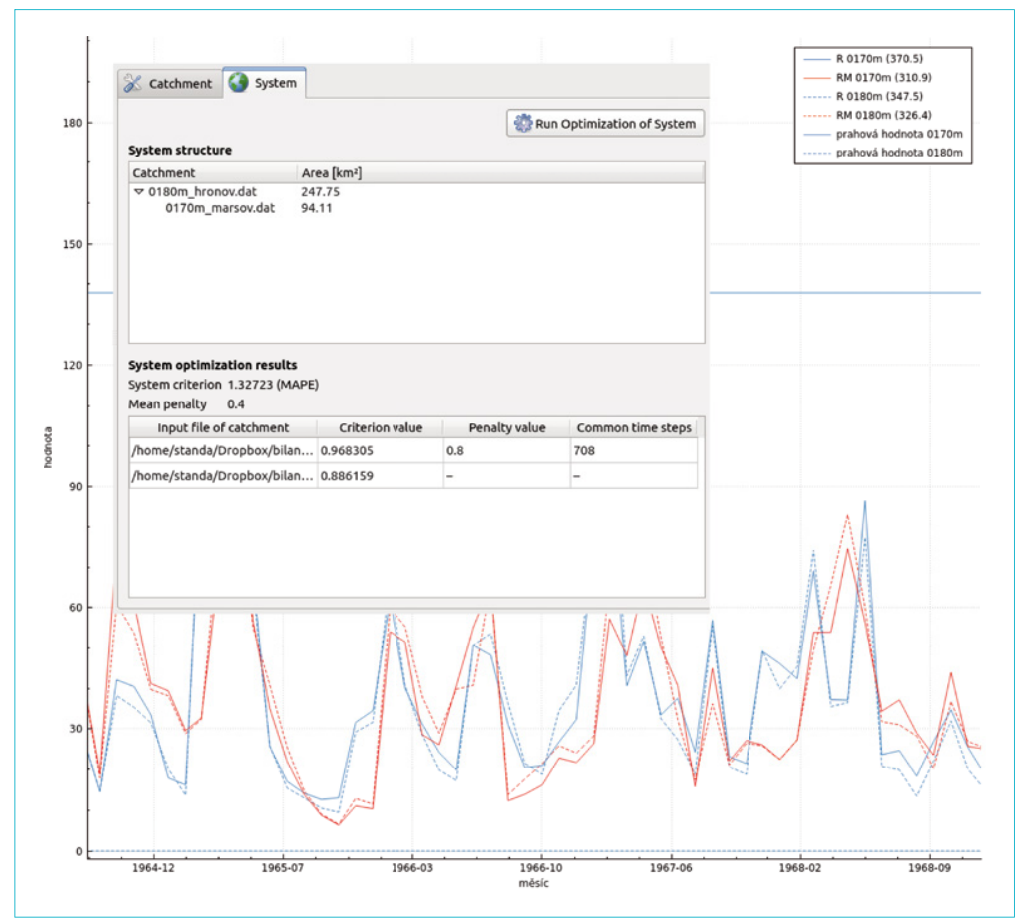

Obr. 4. Př́klad optimalizace dvou povodí DBC 0170 a DBC 0180 na toku Metuje (červeně jsou zobrazeny odtoky pro obě povodí, modře pozorované odtoky) Fig. 4. An example of optimization of two river basins DBC 0170 and DBC 0180 of the Metuje River (red - modelled runoff for the both basins, blue - observed runoff)

uzavřené. Hydrologická bilance je složená z odtokových (odtok povrchový, prímý a základní) složek a složek zásobních (zásoba vody v půdě, podzemních vodách a ve sněhu). Vazby mezi jednotlivými složkami jsou reprezentovány jednotlivými parametry, které lze přenášet na hydrogeologicky podobná povodí. Tento prístup byl také zvolen pro modelování hydrologické bilance $v$ projektu Rebilance zásob podzemních vod (Kašpárek, Hanel aj., 2014), kde pro celé hydrogeologické rajony, které nejsou hydrologicky uzavřené, byly parametry modelu přeneseny z jednotlivých povodí vyskytujících se v daném rajonu. Pro pilotní povodí v České republice byly navíc odvozeny odhady hodnot parametru zásoby vody v půdě (Spa) a parametru ovlivňujícího základní odtok (Grd). Výpočetní algoritmus modelu byl znovu ověřen tím, že výsledky byly porovnávány s výstupy modelů HBV a GR4J (Vizina aj., 2014).

Další možností využití modelu BILAN je modelování dopadů změn klimatu na hydrologickou bilanci, kdy je model nakalibrován pro současné podmínky a následně jsou parametry modelu využity pro modelování výhledových stavů. Vstupem bývají výstupy z regionálních klimatických modelů nebo upravená vstupní data, např. zvýšení teploty vzduchu o $1{ }^{\circ} \mathrm{C}$. Následně je provedena analýza změn hydrologické bilance porovnáním výhledového stavu se současným. Pro současné a výhledové podmínky je navíc možné modelovat dopady při změněném užívání vod, které je uskutečněno pomocí transformace odběrů z povrchových a podzemních vod. Transformace mohou být provedeny pomocí přičtení či odečtení v jednotlivých měsících nebo pomocí násobku jednotlivého odběru. V modelu je též možné nastavit hodnoty neevidovaných odběrů či jejich odhad. Následně je provedena simulace. Pro posouzení, zda je daný zdroj pro zvolený odběr dostatečný, je možné použít výpočet nedostatkových objemů. Nedostatkové objemy Ize nastavit na libovolnou limitní hodnotu, a to jako konstantní, nebo variabilní v jednotlivých měsících. Obvykle se nastavuje hodnota minimálního zůstatkového průtoku nebo průtokové kvantily.

$\checkmark$ modelu je možné simulovat soustavu více povodí. Výsledky automatické kalibrace pro dvě povodí jsou uvedeny na obr. 4. Výhodou tohoto propojení 
je, že nedochází k záporným odtokům na mezipovodí, které v dřívějších simulacích jednotlivých povodí způsobovalo problémy při následných simulacích vodohospodářských soustav.

\section{ZÁVĚR}

Model hydrologické bilance BILAN je vyvíjen ve Výzkumném ústavu vodohospodářském v Praze od 90. let 20. století, avšak za poslední roky doznal výrazných změn, a to především v použitelnosti pro koncové uživatele. Hlavní výhodou modelu je nenáročnost na vstupní data a robustnost. Pro modelování stačí denní či měsíční řady teplot vzduchu a srážkových úhrnů.

Současná verze modelu BILAN poskytuje plnohodnotné grafické uživatelské prostředí, které prostřednictvím interaktivních prvků a grafických výstupů umožňuje pohodlnou expertní kalibraci modelu. Výhodou je také možnost přizpůsobit optimalizační algoritmus, např́klad pro optimalizaci nízkých či vysokých průtoků. Hromadné zpracování dat (např. modelování dopadů klimatické změny na hydrologickou bilanci) usnadňuje prostředí $R$, v němž lze model použít ve formě balíku. Model je k dispozci také jako webová aplikace. Jednotlivé verze modelu jsou dostupné po domluvě u autorů príspěvku.

\section{Poděkování}

Článek vznikl na základě výsledků projektu "Udržitelné využivání vodních zdrojů v podmínkách klimatických změn" (TA01020508), který byl financován Technologickou agenturou České republiky.

\section{Literatura}

Beran, A., Horáček, S. a Hanel, M. (2011) Zjednodušení metody výpočtu potenciální evapotranspirace $\checkmark$ nové verzi modelu BILAN. VTEI, 53, 2011, mimoř. č. III, s. 17-20, príl. Vodního hospodářství č. 11/2011.

Bonacci, O. (1993) Hydrological identification of drought. Hydrological Processes, 7, p. 249-262.

Chang, W., Cheng, J., Allaire, J.J., Xie, Y., and McPherson, J. (2015) Shiny: Web Application Framework for R. Dostupné z: http://CRAN.R-project.org/package=shiny.

Horáček, S., Rakovec, O., Kašpárek, L. a Vizina, A. (2009) Vývoj modelu hydrologické bilance BILAN. VTEl, 51, mimořádné číslo I, s. 2-5, príloha Vodního hospodárství č. 11/2009.

Kašpárek, L. Hanel, L. Horáček, S. Máca, P. and Vizina, A. (2014) Bilan: Bilan water balance model. R package version 2013.12. Dostupné z: http://CRAN.R-project.org/package=bilan, Praha: VúV TGM., v.v.i.

Kašpárek, L., Hanel, M. aj. (2014) Rebilance zásob podzemních vod - Stanovení velikosti prírodních zdrojů podzemní vody v 53 hydrogeologických rajonech - (Aktivita 6, Hydrologické modely) Souhrnná zpráva. Praha: VúV TGM., v.v.i., 27 s.

Máca, P., Vizina, A. a Horáček, S. (2013) Optimalizace parametrů modelu BILAN metodou SCDE. VTEI, 55, 2013, č. 4, s. 1-4, príl. Vodního hospodárství č. 8/2013.

R Core Team (2015) R: A Language and Environment for Statistical Computing. R Foundation for Statistical Computing, Vienna, Austria. Dostupné z: http://www.R-project.org.

Tallaksen, L.M. and van Lanen, H.A.J. (eds) (2004) Hydrological Drought - Processes and Estimation Methods for Streamflow and Groundwater. Amsterdam.

Vizina, A a Hanel, M. (2011) Eliminace ovlivnění průtoku pomocí propojeného modelu hydrologické a vodohospodářské bilance. VTEl, 53, č. 3, s. 20-22, př́loha Vodního hospodářství č. 11/2010.

Vizina, A. aj. (2014) Udržitelné využivání vodních zdrojů v podmínkách klimatické změny. Technická zpráva. Praha: VÚVTGM.

\section{Autoři}

Ing. Adam Vizina, Ph.D. ${ }^{1,2}$

凶adam_vizina@vuv.cz

Ing. Stanislav Horáček, Ph.D.'

凶stanislav_horacek@vuv.cz

doc. Ing. Martin Hanel, Ph.D.,

$凶$ martin_hanel@vuv.cz

${ }^{1}$ Výzkumný ústav vodohospodářský T. G. Masaryka, v.v.i.

${ }^{2}$ Česká zemědělská univerzita v Praze, Fakulta životního prostředí

Príspěvek prošel lektorským řízením.

\section{RECENT DEVELOPMENTS OF THE BILAN MODEL}

\section{VIZINA, Adam ${ }^{1,2}$; HORACEK, Stanislav ${ }^{1}$; HANEL, Martin ${ }^{1,2}$}

${ }^{1}$ T. G. Masaryk Water Research Institute, p.r.i.

${ }^{2}$ Czech University of Life Sciences in Prague

Key words: hydrological balance modelling - BILAN model

- graphical user interface $-\mathrm{R}$ - Shiny - web application

The BILAN model has been used in a number of research projects and hydrological studies dealing with estimation of water balance for European catchments. This paper is focused on the recent development of the model during last years. The model changes include both core development (new variables representing water use, optional calibration for a system of catchments, saving of state variables) and enhanced user interface that was extended by new graphical outputs and controls allowing interactive use of the model. The $R$ package interface and web application are also introduced. Finally, studies that use the model for simulation of catchment behaviour for current and climate change conditions are mentioned. 